\title{
Du patient à l'image radiologique : une sociologie des transformations
}

Dominique Boullier

\section{(2) OpenEdition \\ 12 Journals}

Édition électronique

URL : https://journals.openedition.org/tc/500

DOI : $10.4000 /$ tc. 500

ISSN : 1952-420X

Éditeur

Éditions de l'EHESS

Édition imprimée

Date de publication : 1 mars 1996

ISSN : 0248-6016

Référence électronique

Dominique Boullier, "Du patient à l'image radiologique : une sociologie des transformations »,

Techniques \& Culture [En ligne], 25-26 | 1996, mis en ligne le 28 octobre 2005, consulté le 29 septembre 2022. URL : http://journals.openedition.org/tc/500 ; DOI : https://doi.org/10.4000/tc.500

Ce document a été généré automatiquement le 29 septembre 2022.

Tous droits réservés 


\section{Du patient à l'image radiologique : une sociologie des transformations}

Dominique Boullier 